\title{
Haitian-ness, Frenchness and History
}

Historicizing the French Component of Haitian National Identity

\section{Gérarde Magloire}

\section{CpenEdition}

Journals

Édition électronique

URL : http://journals.openedition.org/plc/686

DOI : $10.4000 /$ plc. 686

ISSN : 2117-5209

Éditeur

L'Harmattan

\section{Édition imprimée}

Date de publication : 1 janvier 1997

Pagination : 18-40

ISSN : 1279-8657

Référence électronique

Gérarde Magloire, " Haitian-ness, Frenchness and History », Pouvoirs dans la Caraibe [En ligne], Spécial | 1997, mis en ligne le 15 mars 2011, consulté le 19 avril 2019. URL : http:// journals.openedition.org/plc/686; DOI : 10.4000/plc.686 


\section{Haitian-ness, Frenchness and History. Historicizing the French Component of Haitian National Identity}

par Gérarde MAGLOIRE Ph. D. in French Studies, New York University, U.S.A.

«History raises questions of its times more than those of the period it is supposed to cover. »

Benedetto Croce 1912

The idea of nation or national identity as a cultural construct entailing processes and relations rather than constituting a timeless essence - is well substantiated in the case of the elite in Haiti. Unique historical circumstances and developments of this island republic make it a particularly elucidating example in nation-building amongst France's ex-colonies : its very small European population, its early independence, its status as the modern world's first black republic and the isolation and hostility it faced from the slave holding powers after its liberation from France. After Haiti gained its independence in 1804, French civilization and later - more specifically - French language and culture continued to be ones of domination by which a small group of former affranchis ${ }^{1}$, or freedmen, differentiated themselves from the masses of ex-slaves. The colonial socioeconomic system and sociocultural structures were perpetuated and education - largely

1. The affranchis numbered 28,000 in 1795 and were mostly mulattoes, born of a French father and a slave mother and also included a small number of blacks freed through manumission. Not all mulattoes were free : 40,000 were slaves - a relatively small number amongst 450,000 slaves. James Leyburn, The Haitian People, New Haven, Yale University Press, 1941, p. 18. 
inaccessible to the masses - remained not only a weapon of social control, but became an important locus for forging and preserving national identity for the elite. It was especially elite control of history writing that contributed to imposing the French civilization and French cultural models for over a century.

J-C Dorsainvil's Manuel d'histoire d'Haiti ${ }^{2}$, still read today by Haitian schoolchildren between the ages of eleven and fourteen, was first approved on March 29, 1924 by the Conseil de l'Instruction Publique d'Haïti (Haitian Council of Public Education). Written in collaboration with the Frères de l'Instruction Chrétienne ${ }^{3}$ who ensured a large circulation and quasi monopoly of history textbook production, the Manuel d'Histoire d'Haïti remains the history reference book in use today in Haitian classrooms ${ }^{4}$. The Manuel bears the characteristics of a truly «national» history with emphasis on national unity, romantizing of battles of liberation, hailing national heroes, etc. It would be of interest to examine this pedagogical tool as a forger and transmitter of national identity and collective memory of the Haitian elite in order to address two fundamental questions. What are some of the means - besides the French language ${ }^{5}$ - by which French culture is

2. Justin-Chrysostome Dorsainvil, Manuel d'Histoire d'Haïti, Port-au-Prince, Éditions Henri Deschamps, 1925 [1934, 1958]. A slightly different version, the Histoire d'Haiti - à l'usage des candidats au Certificat d'études primaires, 1942 [1943, 1945] was published for pupils preparing for the Certificat d'études primaires, a state exam that prepares youngsters for middle school. The contents and style of this version are identical to the Manuel except for the omissions of a summary at the beginning of each subchapter and of the $23^{\text {rd }}$ chapter on the Catholic Church in Haiti. It is prefaced by Dantès Bellegarde the then Minister of Education and a strong proponent of perpetuating the use of French culture and language to educate Haitians. The Manuel is prefaced by Père Archange, a priest who addresses the pupil using «Chers enfants » (Dear children).

3. This male religious order was active in the field of pedagogy not only in Haiti, but in French colonies also.

4. Although there have been numerous reprints of this history manual, the chronology ends in 1957 with the rise to power of François Duvalier. There is mention of the dates of Jean-Claude Duvalier's arrival in office in 1971 in the section listing the heads of state; however, Haitian history ceases in 1957. The manual remains in essence the same as its 1924 edition.

5. The role of the French language in colonial and post-colonial orders is psychoanalyzed in Frantz Fanon's $1^{\text {st }}$ chapter of Peau noire masque blanc, Paris, 
appropriated and expressed by this group ? How are the nine-tenths of the population of solely Creole-speaking, Voodoo-practicing rural masses integrated into this definition of Haitian-French national identity?

For purposes of clarity and methodology, this study will be conducted in two parts. The first half, The Actors of History, will expose some of the social forces and processes in Haiti in the nineteenth century as well as major developments on the international scene that led a tiny but powerful ruling class to define « Haitianness » using the French cultural model. In light of this historical backdrop, the second part, The Agents of Memory, will consist in examining Dorsainvil's history manual.

\section{THE ACTORS OF HISTORY}

Following Max Weber's trailblazing work that dismantled reified entities such as «nation», «people» and «state», social scientists today emphasize the role of intellectuals - particularly historians - and politicians in formulating national identities. The wave of nationalism that shook Europe in the nineteenth century resulted in various enterprises of national self-definition especially through the appropriation of history writing - patterns that younger nations of the twentieth century would follow :

«Historiens, écrivains ou poètes, selon les pays, ont toujours été chargés de formuler les termes du projet politique, en entretenant ou en créant de toutes pièces une mémoire qui fonde la volonté d'un avenir commun. Les écrivains nationalistes des «nouvelles nations» d'Asie et d'Afrique empruntent aujourd'hui, pour mobiliser les énergies, les thèmes et les accents des nationalistes européens du $\mathrm{XIX}^{\mathrm{e}}$ siècle $^{6}{ }$.

Haiti, however, does not rank among these «new nations ». It was the second colony to win its freedom in the New World after the

Minuit, 1955, «Le Noir et le langage ». For the historical and socio-linguistic context of French and Creole in colonial and post colonial societies see Dany Bebel-Gisler's La langue créole, force jugulée : Etudes socio-linguistiques des rapports de force entre le créole et le français aux Antilles, Paris, L'Harmattan, 1981.

${ }^{6}$. Dominique Schnapper, La France de l'intégration, Paris, Gallimard, 1991, p. 77. 
United States. Haiti therefore did not have fellow ex-colonies to emulate, to profit or gain support from. As C.L.R. James observes :

«For the first century and a half of Haiti's existence there was no international opinion jealous of the independence of small nations ; no body of similar states, ready to raise a hue and cry at any threat to one of their number ; no theory of aid from the wealthy countries to the poorer ones (...) Yet it has preserved the national independence (...) and out of this has come something new which has captured a continent and holds its place in the institutions of the world $»^{7}$.

Haiti clearly followed the European, in particular the French civilization model, throughout the 19th century - during and not after the era of intense nationalism. Haiti was thus a new nation amongst the powerful nations of the West - or at least it strove to be accepted as such. The Haitian dominant class was oriented towards France and the political and cultural processes on the other side of the Atlantic therefore had all the more impact on Haiti's national development.

Indeed, even though Haiti as a nation remained isolated diplomatically for much of its early history ${ }^{8}$, the Haitian elite held close contacts with France especially from the mid to late nineteeth century. Many of them had fathers and grandfathers who were French and they sent their children to study in French lycées and universities?. The literati were in touch with European politics and intellectual development was concomittant with that of France and Europe in general. Demesvar Delorme (1831-1901), an influential Haitian writer, thinker and diplomat was a friend of Jules Michelet, Alphonse Lamartine, and Victor Hugo. Haitian philosopher, Louis-Joseph Janvier (1855-1911) studied philosophy with Auguste Comte's disciple, Pierre Lafitte ${ }^{10}$. In the realm of history, Beaubrun Ardouin

${ }^{7}$. C.L.R. James, The Black Jacobins, New York, Random House, 1963, p. 393.

${ }^{8}$. Brian Weinstein and Aaron Segal, Haiti : Political Failures Cultural Successes, New York, Praeger, 1984, p. 111. The Vatican did not recognize Haiti's independence until 1860 and the United States until 1862.

9 . Léon-Francois Hoffmann «Francophilia and Cultural Nationalism » in Haiti Today and Tomorrow, New York, University Press of America, p. 60.

${ }^{10}$. Patrick Bellegarde-Smith, «Haitian Social Thought in the Nineteenth Century : Class Formation and Westernization ", Caribbean Studies, Mar. 1980, Vol. 20, $\mathrm{n}^{\circ} 1$, p. 29. 
(1796-1865) and Joseph St. Rémy (1815-1858) - historians who wrote at a time when Haitian history took its definitive character - utilized the models of their French contemporaries, Augustin Thierry and Adolphe Thiers - both romantic historians ${ }^{11}$.

Like many of their French counterparts, these Haitian intellectuals were gaining political weight which, in Haiti's case, was especially enhanced in a society where only $2 \%$ of the population was literate. It was in the mid-nineteeth century that the Haitian elite ${ }^{12}$ was reaching its ascendancy and began to mount the ideological bases to legitimize its own power. This period was critical in Haitian history because of the aforementioned contacts with positivist and liberal France of the first half of the nineteeth century. Indeed, the imported idea that science and progress were in the hands of a few capable enlightened individuals leading the untutored masses was capital in determining the development of cultural and national identity in Haiti. The adoption of the French cultural model to define the Haitian nation was therefore largely a matter of class interest, a concerted action to keep the less educated and ambitious elements (as well as the masses) at bay by monopolizing the state apparatus and educational system and controlling the writing of history. Reflecting on the role of elite education throughout Haiti's history, Haitian writer Ghislain Gouriage states :

«L'enfant haïtien entre à l'ecole pour apprendre à oublier qu'il est noir. Et chaque fois qu'il gagne la rue, c'est pour mesurer sa solitude et compter les pas qui l'éloignent de ces illettrés, de ces vaudouisants dont il aura peut-être un jour à régler le destin $»^{13}$.

Closely tied with the control of education is the writing of history and its transmission. In his article, A work of Combat : Mulatto historians and the Haitian Past, 1847-1867, David Nicholls examines

${ }^{11}$. Ibid, p. 21.

12. Anthropologist Sidney Mintz offers an operative definiton of the elite : « The elite live by controlling and taxing the rural masses, and find their sustenance and their power in rural productivity. Elite and peasantry, then, are bound together in unequal and interdependent relationships in Haiti as they are in other less developed societies of a similar kind », Caribbean Transformations, New York, Columbia University Press, 1989, p. 271.

13. Gouriage, Ghislain, La Diaspora d'Haïti et l'Afrique, Editions Naaman, 1974, p. 82 . 
the way in which a circle of mid-nineteeth century historians - from Haiti's mostly mulatto French-educated, French-speaking elite - rewrote Haitian history to strengthen the position of this ruling class and to justify its ascendancy :

«The general effect of the mulatto version of the Haitian past is however, to encourage Haitians to unite under the leadership of the most patriotic, civilized and technically qualified group in the country, to legitimate the mulatto ascendancy in the social and economic field, and to lend weight to their claim to guide and control developments in the political sphere ${ }^{14}$.

The most «civilized and technically qualified » group clearly implies the French-educated ruling elite. It is interesting to note the double value system of mulatto ideology summarized by Nicholls and which underlies the works of these self-consciously patriotic historians led by St. Rémy and Ardouin. It includes the insistance on national unity, race solidarity (of blacks) and virulent anti-colonialism on one hand, and the belief in superior civilizations with France as the model to be emulated, on the other. Africa and generally all things African, especially the Voodoo religion, are considered as barbarous and a hindrance to progress and civilization ${ }^{15}$. Although the contents of these history books are steeped in ideology and have been discredited for their lack of objectivity, they have nonetheless left their mark in the formulation of Haitian identity - as we shall later see - in their emphasis on the French cultural element by downplaying the African ancestry component. This link between the self-definition of a group and formulation of an interpretation of the past is significant. Immanuel Wallertstein explains :

«Why does one need a past, an 'identity' ?... Pastness is a central element in the socialization of individuals, in the maintenance of group solidarity, in the establishment of or challenge to social legitimation. Pastness,

14 . David Nicholls, «A Work of Combat : Mulatto Historians and the Haitian Past, 1847-1867 », Journal of Interamerican Studies and World Affairs, Feb. 1974, Vol. 16, $\mathrm{n}^{\circ} 1, \mathrm{p} .24$.

${ }^{15}$. Ibid, p. 35 . 
therefore, is pre-eminently a moral phenomenon, therefore a political phenomenon, always a contemporary phenomenon ${ }^{16}$.

However, the fact that the Haitian ruling class patterned itself after the French cultural model must not be viewed solely as a matter of class interest and only within the internal social processes of Haiti, but should also be placed in the international context and developments in the 19th century. When Haiti emerged as an independent nation of mostly ex-slaves in 1804 after a tortuous twelve year war of liberation, it was immediately ostracized by the international community. Indeed, slavery was the basis for much of the economic world order with the Western powers holding colonies in the Caribbean and Central America and the United States practicing slavery on her own soil. Haiti - an island in more ways than one - was therefore left to her own devices to rebuild from scratch a national economy and to create a sense of national identitiy and unity among a quarter of a million illiterate former slaves. Facing hostility and isolation from the great powers, Haiti's early leaders had little choice but to construct the fledgling republic on the model of French culture and society.

To these important conditions must be added the fact that Haiti had been a Caribbean colony. In as such, colonialism in St. Domingue (name of colonial Haiti) had been sweeping and thorough leaving - as T. Munroe notes - no "cultural hinterland of identifiable political structures"17 which could have served as an option instead of the colonial administration. Indeed, the great historical figure, Toussaint Louverture, ex-slave who had learned to read and write in his forties, understood the immutability of these forces of history. French, therefore, became the "national » language, a Haitian version of the Code Napoléon (French Civil Code) was adopted as well as the French system of education and French adminstrative structures ${ }^{18}$.

16. Immanuel Wallerstein, «The Construction of Peoplehood: Racism, Nationalism, Ethnicity » in Race, Nation, Class, Ambiguous Identities, Chris Turner, trans., London, Verso, 1991, p. 78.

${ }^{17}$. Cited in Helen M. Hintjens. Alternatives to Independence : Explorations in Post-Colonial Relations, Brookfield VT, USA, Dartmouth Publications, 1995, p. 33.

${ }^{18}$. It should be noted nonetheless that although the French civilization and French cultural models were the most promoted for Haiti's development, there were brief or partial experiments with the Anglo-Saxon system of liberal individualism and its 
«The very concepts of the state and nation were, for the Haitians of 1804, Western concepts. Thus the social organization which helped to preserve political independence was created with a hate love-opposition of a kind. Wanting to deny the oppressive French cultural universe, the Haitians nevertheless expressed their nationality in a form that retained certain concepts of Western capitalism and borrowed most features of formal government structure from France $\gg 19$.

It is interesting to note how Haiti's self-defintion continued to be shaped to a certain extent by the way the rest of the world looked at this island Republic. Haiti's dual cultural and national identity was for the first century of its national existence tipped in favor of the French component partly because of how Haiti's self liberation and selfdetermination was viewed in a colonial world order. It was an enclave of radicalism, the result of the first successful slave revolt in modern history. The dominant class of the young nation, eager to find a place in the sun within the international order, tried to disassociate itself from the radicalism that Haiti's independence conferred upon it. As the Haitian newspaper, Manifest of February 18, 1844 read, «Ou Haïti prend rang au niveau des peuples civilisés d'Europe ou son nom disparaît ${ }^{20}$. Indeed, the Haitian elite's insistance on its French culture, language and institutions grew all the more vocal as time went on.

Even when the two colossal powers that had contributed the most to keeping Haiti isolated - the United States and the Vatican finally recognized Haiti's independence in the 1860's (over half a century later), the Haitian ruling class remained on the defensive concerning its insistance on the French character of Haitian national identity. This paradox merits explanation.

scientific and technical basis of social development. When Haiti was divided into two states under Henri Christophe's rule, the northern State was transformed into a kingdom in 1811 - similar to the St. James model of a liberal monarchy English style. Later under the Presidency of Nord-Alexis (1902-1908) a debate erupted among Haiti's leaders and intellectuals over the proposal to convert to the Anglo-Saxon model promoted notably by Auguste Magloire. David Nicholls, op.cit., p. 137.

19. Jean Casimir-Liautaud, «Haitian Social Structure in the Nineteeth Century», Working Papers in Haitian Society and Culture, New York, ARP-Yale 1975, p. 44.

20. Patrick Bellegarde-Smith, Race, Class and Ideology: Haitian Ideologies for Underdevelopment, New York, AIMS, 1982, p. 8. 
The United States recognition of Haitian independence in 1862 certainly came as a result of the American Civil War and its implication for the practice of slavery; however, it also announced the beginning of American expansionism. Consequently, as Haiti was gradually drawn into the economic orbit of the United States, the more Haitian elite displayed cultural nationalism by tightening its claims to Frenchness. This was not only for fear of losing her sovereignty ${ }^{21}$ but because of the revulsion from the racism expressed in the Jim Crow practices in the U.S. The Haitian writer Georges Sylvain (1866-1925) said even before the American occupation of Haiti (1915-1934) :

«What would become of us, lost in the mass of enslaved New World Blacks ? A pinch of Anglo-Saxon dust !... The more we hold on to our French culture, the more likely we are to keep our Haitian personality $»^{22}$.

There is yet another important development at this time that contributed to the systematic identification of the Haitian upper class with the French. As a result in 1860 of President Nicolas Geffrard's initiative to re-establish ties with Rome after a schism of 55 years $^{23}$, there was an influx into Haiti of French Catholic priests, nuns and prelates - many from Quimper, Brittany. Propagating the faith was not their primary mission even though they did wage a sort of war against Voodoo - the Haitian people's religion. These French religious congregations were allowed to open private schools and were entrusted with the task of gallicising elite children. Haitian social scientist Kléber Viélot writing in the late 1960's underlines the historical significance of this concordat in widening the cultural gap between the French educated ruling class and the national community of Creole speaking masses :

«The prevailing tendancy to imitate the French schooling system faithfully increased under the influence of the French nuns and priests, whose

21. Between 1857-1915 the United States intervened militarily in Haiti nineteen times. Also, as early as 1868 President Andrew Jackson contemplated on annexing both Haiti and the Dominican Republic. Bellegarde-Smith (2), p. 14.

${ }^{22}$. Quoted in Hoffmann (1), p. 64.

23. The Vatician had rejected the 1805 Haitian Constitution which stipulated complete separation of Church and State, approved divorce and gave illigimate children the same rights as legal children. Leyburn, p. 119. 
primary duty was to perpetuate French culture in Haiti. In the classroom, the Haitian pupil felt in his mind and heart more French than Haitian ${ }^{24}$.

So complete was this mission of frenchification that Haitian history was not taught to children in these Catholic schools until $1946^{25}$.

Once again, reinforcements of the kind mentioned above must be placed in the context of Western thought at the time ${ }^{26}$. It is perhaps not necessary to elaborate on the obvious implications of social Darwinism and scientific - which were fully developed between the mid and end of the 19 th century $^{27}$ - for a republic established, run and populated by Blacks. It should be noted, however, that Haiti became a handy target to justify such ideologies. Indeed, as a result of the «scramble » for Africa in the late nineteeth century by the European powers, colonial propaganda machine began slandering Haiti, pointing to her as proof that Blacks could not govern themselves. France, in particular, with her ideologically propelled mission civilisatrice pointed to Haiti's difficulties to justify its new wave of colonialism in Africa. These difficulties - political violence and instability, socioeconomic problems inherited from the pre-independent era and compounded by Haiti's isolation and its colossal indemnity to France certainly gave the European colonists much to say about Haiti's economic and social «backwardness »: «Les nègres, laissés à euxmêmes, ont montré ce dont ils étaient capables. Haïti marche à une

${ }^{24}$. Kléber Véliot, «Primary Education in Haiti » In The Haitian Potential, New York : Teachers College Press, 1975, p. 118.

25. Ibid.

26. Enterprises or efforts of gallicization of the Haitian school programs were more or less continuous throughout the end of the $19^{\text {th }}$ century with the sponsorship of the Alliance Française beginnning in 1880's. Various intiatives were taken, for example, under the presidencies of L. Félicité Salomon in the mid-1880's and that of Tancrède Auguste in 1912-1913. Similar educational policies were implemented for several decades into the $20^{\text {th }}$ usually in conjunction with the religious teaching orders which were eventually put on the payroll of the Haitian State. It was evidently for economic reasons that Haitian leaders hired priests and nuns to teach in State schools.

27. William B. Cohen, The French Encounter with Africans 1530-1880: White Response to Blacks, Bloomington : Indiana University Press, 1980, p. 262. 
ruine complète », concluded Henri Castonnet des Fosses, a Frenchman who wrote on Haiti in $1885^{28}$.

It was, however, by insisting more than ever on their French culture and language that the Haitian intelligentsia took up their pens to defend Haiti from the wide spread slander produced by imperialist powers. In fact, many of the literati, assimilated the ideology of the superiority of the French civilization by boasting that Haitians (meaning themselves) have rehabilitated the black race for they are living proof of gallicised, civilized blacks. «France is the capital of nations. Haiti is the Black France » declared Louis-Joseph Janvier whose defense of Haiti in La République d'Haiti et ses visiteurs and l'Egalité des races are renowned amongst the production of apologies for Haiti written in the late nineteeth century ${ }^{29}$.

The «normalization» of the relations with the U.S and the Vatican opened Haiti to more and more visitors ; however, the political violence and instability, the extreme poverty due to class divisions couched in racial terms and inherited from colonial days, were viewed as savagery by observers. Voodoo, too, became subject to sensationalist press coverage and travel literature. Pamphlets denigrating Haiti and the extremely derogatory book published by British minister Sir Spenser St. John ${ }^{30}$ gave way in the interwar years to a spate of books of dubious titles such as Cannibal Cousins (1934), Black Bagdad (1933), Voodoo fire in Haiti (1935) ${ }^{31}$. It is no wonder that Haiti's bad press portraying the country as savage became an obsessive concern of the Haitian elite who considered themselves wholly integrated into French culture.

${ }^{28}$. Quoted in Hoffmann (2), p. 29.

${ }^{29}$. Hoffmann, (1) p. 62.

30. Hayti or the Black Republic, $2^{\text {nd }}$ ed., London, 1889. James Leyburn's reviewed St. Johns book: «The British Minister to Haiti was an acute observer with a good literary style; but he had a profound antipathy to the country and its ways. The purpose of his book is to show the general decline of Haiti during the 19th century, and to prove the existence of cannibalism as an essential part of 'Vaudoux,' Biting, sarcastic criticism ». Leyburn, op. cit, p. 334.

31. Brenda G. Plummer, Haiti and the Great powers, 1902-1915, Baton Rouge, Louisana State University Presss, 1988, p. 73. 
Africa as a cultural and societal model, therefore, was generally rejected by the ruling classes who disregarded altogether the culture of the Haitian masses (accounting for $90 \%$ of the total Haitian population). It took a great national trauma such as the American occupation (1915-1934) with its clearly racist practices to draw the attention of the elite to the Haitian masses. It was during this period that the father of Haitian ethnology, Jean Price-Mars - without discounting the French element of Haitian national identity - argued in favor of Haiti's African roots. In his classic work, Ainsi parla l'oncle (1928), Price-Mars described peasant life with much insight and richly informed Haitians of their unique and vibrant Afro-Haitian culture. Indeed, this book became the bible of indigénisme and was a significant contribution of the more universal version, négritude. However, as mainly a cultural and intellectual movement that resulted in the flourishing of Haitian literature and $\operatorname{art}^{32}$, indigénisme had little consequences - as we shall see in the Manuel d'histoire d'Haiti - on the cooperation between the elite and the masses.

\section{THE AGENTS OF MEMORY}

In situating Dorsainvil's Manuel d'histoire d'Hä̈ti in Haitian historiography of history manuals for children, some important facts should be noted. First, the teaching of Haitian history did not begin until 1848 - over 40 years after Haitian independence - and the formal production of history textbooks began around $1860^{33}$.

From 1860 until the publication of Dorsainvil's manual in 1924, a number of other history textbooks came into use with varying

${ }^{32}$. Indigénisme in its political form, noirisme was exploited by politicians after the American occupation - especially by François Duvalier, Papa Doc, who achieved power through this ideology and carried out one of the most repressive and violent dictatorships in Central America. Michel-Rolph Trouillot, Haiti : State Against Nation, New York, Monthly Review Press, 1990, p. 132.

33. Catts Pressoir attributes this lag to the need for "recul" or hindsight. L'Histoire de l'enseignement en Haïti, Mexico, Instituto panamericano de geographia e historía, 1950 , p. 31. 
degrees of success ${ }^{34}$. The most influential and widely used ones were Robin Enélus' Abrégé de l'histoire d'Haïti first published in 1875 and recommended by the Commission de l'Instruction Public (Commission of Public Education) and the Petite Histoire d'Haïti à l'usage des écoles primaires by Dorsainvil's brother, Jean-Baptiste Dorsainvil (first published in 1898 and approved by the Ministry of Public Education the same year). Haitian history in these manuals were told in the traditional political history form with questionnaires at the end of each chapter. Numerous editions of both textbooks appeared and were used almost exclusively for a quarter of century ${ }^{35}$.

Justin Chrysostome Dorsainvil's classic manual (1924) was written under the American occupation of Haiti. It was in the revival of patriotism at this time that national history in Haiti was regenerated. Extolling Haiti's glorious past and creating a historical "doctrine" was a priority for Haitian educators and leaders ${ }^{36}$. The threat of the American occupiers to Haitian national identity mentioned earlier gave impetus to the drafting of Dorsainvil's Manuel, which became a sort of official manual of Haitian history for children ${ }^{37}$.

\section{One Haiti}

A recurrent notion throughout the Manuel d'histoire d'Haïti and which is not uncommon in history textbooks of the «fatherland » - is that of national unity. In the Manuel the cultural and social rifts

34. The ones approved by the Ministry or Council of Public Education in Haiti were : Dantès Fortunat's, Nouvelle Géographie et Histoire de l'île d'Haïti, Paris, Henri Noirot, 1888 ; Dr Roche-Grellier's, Histoire d'Haïti à l'usage des écoles, Paris, A. Rousseau, 1892; Sténio Vincent and Dantès Bellegarde's, L'Année enfantine d'Histoire et de Géographie d'Haïti, Bruxelles, Société Belge d'Imprimerie, 1913 ; Windsor Bellegarde and Justin Lherrisson's, Manuel d'Histoire d'Haïti à l'usage des écoles de la République, Port-au-Prince, Imprimerie St. Jacques, 1914.

${ }^{35}$. Pressoir, op. cit, p. 36.

36 . Ibid., p. 34.

37. The recourse to the teaching of history in times of nationalist revival is a common thread that runs through societies and cultures throughout the world. The drafting and production of the Petit Lavisse history manual at the beginning of the French Third Republic after the French defeat in the Franco-Prussian war is a case in point. 
within Haitian society inherited from the French colonial period seem to dissipate after independence. Even in the preface, where the address to young haitian readers beginning with the paternalistic «Chers enfants ", the emphasis is immediately placed on the War of Independence - the only moment in Haiti's history in which the affranchis (the future elite) and the slaves rose as one man against the French colonists : "Comme vous serez heureux et fiers à parcourir les pages qui résument la glorieuse épopée de notre Indépendance Nationale ! »

However, shortly after independence, as early as 1820 , when the slave leadership that had led most of the Haitian revolutionary armies had been eliminated, the conquest of the new state apparatus by the former affranchis began ${ }^{38}$. The consolidation of affranchis-derived elite met at first little opposition from the illiterate masses who remained outside of civic life. However, a small group of more literate and ambitious blacks, generally less educated and less integrated into French culture challenged the rise to power of the mulattoes. Much of Haiti's tumultuous history is marked by this fratricidal struggle. Admittedly, the Manuel is a concise and essentially political, événementielle (factual) history of Haiti destined for children. However, the imperative to keep things simple does not explain the omission of practically all cultural divisions and social strife throughout the textbook. Conflicts are couched strictly in political terms. Indeed, Dorsainvil recounts chronologically, fact per fact, the events in Haiti's turbulent political history. The young reader has the impression that much is being told of the endless upheavals of his country's history as the terms of each sub-chapter indicate: Expédition, Insurrection, Campagne, Complot, Affaire, Guerre civile, Agitation, Assassinat, Scission, Siège, Déportation etc.. However, the underlying social causes of these political upheavals are seldom indicated.

${ }^{38}$. Bellegarde-Smith, (1), p. 13. 


\section{Borrowed Robes}

That the elite expresses Haitian nationality through French political, social and legal institutions is perhaps the most patent French feature of the Manuel. In the section that covers the post-independence period, official and administrative Haiti is (and still remains today) French. From the Code Pénal to the Code Napoléon, from the organization of the government, courts and army, to the small-scaled educational system, Haiti has kept all in French form for over a century and a half after independence. However, the last three institutions mentioned never became instruments of integration of the Haitians into the nation as they did in France at the end of the nineteenth century ${ }^{39}$. Instead, they served to preserve rigid cultural and socio-economic barriers and were geared towards individual gain and securing power ${ }^{40}$.

Throughout Dorsainvil's manual, elite children of Haiti learn the history of their country with the aid of over two-hundred illustrations of Haitian national emblems : pictures and photos of heavily decorated heads of state and generals, maps, battle scenes, government buildings, légion d'honneur, monument aux héros de 1803, national seals and currencies which are typical of the Western culte de la patrie, especially of the French Third Republic. Indeed, while Haiti's selfdefiniton and sovereignty are emphasized, they are couched in French cultural terms. At times naive comparisons are made - undoubtedly for pedagogical purposes - between France and Haiti in order to reconcile the contradiction between national self-assertion and cultural emulations. For example, Dorsainvil does not hesitate to point out that the Haitian Second Empire of Faustin Soulouque was established three

39. The process by which all groups of a given society are integrated into the national community was first systematically studied by Nobert Elias in the 1930's. According to Elias, it was the spread of political democracy through the parliamentary system in European societies that the lower strata were incorporated into the "nation". Gérard Noiriel, «La Question nationale comme objet de l'histoire sociale », Genèse, mai 1991, p. 82.

40. Michel-Rolph Trouillot in his work Haiti State Against Nation, articulates in Haiti's case the relations between nation-building or cultural identity and the state: «...the correlation is not a simple one. Nation-building can operate within the state, against the state, or in the name of the state », p. 25 
years before France's Second Empire. «L'histoire a de curieuses coïncidences : le second empire haïtien fut fondé en 1849: le second empire français, trois ans plus tard, l'année même du sacre de Faustin $1^{\mathrm{er}} \gg{ }^{41}$.

Another example of this cultural imitation and national reaffirmation in relation to Haiti's cultural mother is the encounter with the French mission sent by Louis XVIII to «re-negotiate » Haiti's independence which France had not yet recognized. Dorsainvil succinctly recounts the failed efforts of the French officials to bribe with medals and titles the Haitian government into submission :

«On avait cru, à Paris, que les distinctions honorifiques éblouriraient les Haïtiens : Mille croix du Lys, dix de Saint-Louis, douze de la Légion d'Honneur à l'effigie de Henri IV, devaient récompenser les fonctionnaires antipatriotes. On ne trouva pas, en toute Haïti, une seule poitrine qui consentit à les recevoir » ${ }^{42}$.

The above display of thorough knowledge of French honorary distinctions, institutions and history is a subtle but powerful form of cultural appropriation.

Clearly present throughout the Manuel is the careful balancing act of «standing up » to the French and yet not discrediting them in anyway. There are, indeed, gaps in the narrative in regards to negative policies of the French toward Haiti. In particular, the astronomical indemnity demanded by Charles $\mathrm{X}$ in exhange for the recognition of Haiti's independence (twenty-one years after the fact) made progress and stability unattainable for the fledgling republic. Haiti had little choice but to borrow from French money lenders to pay the great sum of one hundred and fifty million francs in gold. The original amount was constantly re-negotiated (twenty years later reduced to sixty million) crippling Haiti financially for over a century ${ }^{43}$. Although the Manuel concedes the unfair nature of the reparations, it never mentions

${ }^{41}$. Dorsainvil, p. 228.

42. Ibid, p. 188.

43. In a detailed commentary on these reparations, Frédéric Marcelin's criticizes this concession to France on the grounds that the Haitian people were not consulted about this historical decision. Haïti et l'indemnité française, Paris, Imprimerie Kugelmann, 1897. 
the true implications for Haiti's fate. In fact, a light-hearted anecdote apparently aimed at making a national hero of President Jean-Pierre Boyer - is awkwardly dropped into the narrative. Boyer - who ruled Haiti for twenty-three years - was the president who signed the indemnity agreement with France :

«On raconte que Louis-Philippe, voulant lui rendre hommage, l'appela Prince à l'audience qu'il lui accorda, et, comme Boyer se récriait : « Sire, je ne suis pas prince, j'ai été le chef d'une petite République », le roi de France lui serra affectueusement la main et répliqua : «Quand on a gouverné un million d'hommes pendant vingt-cinq ans, on s'est élevé au rang des princes ${ }^{44}$.

\section{Haiti without Haitians}

In general the French component of Haitian national identity is manifest throughout the Manuel less because of explicit references to things French than because of the conspicuous lack of the African heritage of Haitian culture... That the overwhelming majority of Haitians (95\% - $97 \%$ in 1804 and $85 \%$ - $90 \%$ today) speak only Creole, a separate and distinct tongue - and not French, and that their religion is Voodoo - and not only Roman Catholicism are essential facts about the make-up of the Haitian people. However, these facts do not appear in the Manuel d'histoire d'Haiti.

Omissions of the kind mentioned above become patent when one considers Dorsainvil's description allotted to the Arawaks - the indigenous people of Haiti who were almost entirely decimated by the Spaniards before the arrival of the French to the island. The language, customs, art, poetry, and social organization of these Caribbean Amerindians are described in the Manuel. There is even mention of certain aspects of their culture which still survive today in Haiti such as words from their language and their type of dwelling, the ajoupas ${ }^{45}$. Of the blacks who later populated the island, however, we know nothing except that they were from African tribes. Absent from the Manuel is any reference to the slaves' burgeoning culture in the eighteenth century and certainly nothing at all about the culture and social

\footnotetext{
${ }^{44}$. Dorsainvil, p. 195.

45 . Dorsainvil, pp. 7-8.
} 
organization of the Haitian masses in the nineteeth and twentieth centuries ! For example there is no mention of the communal system of labor today (the konbit), of the functional polygamy, of Creole, nor of the oral literature (tales, story telling traditions), dance and various art forms ${ }^{46}$.

Perhaps the most flagrant omission of the Afro-Haitian element of Haitian national identity is the silencing of $V_{\text {oodoo }}{ }^{47}$ in the narrative. The key role of Haiti's folk religion in the slave rebellions and the War of Independence is well known and documented. It was the slaves drumbeats sending signals to each other accross plantations that allowed them to organize themselves and constitute a real force against the French colonists ${ }^{48}$. That the affranchis joined their ranks and shared the leadership of the revolutionary armies is a later development. The word Vaudou appears but once in the entire text in the account of the Cérémonie du Bois Caïman - the rallying site of the first concerted slave rebellion of the War of Independance. However, the leader of the ceremony, Boukman, is «Jamaican-born» and Voodoo is refered to as «the main religion of the Dahomeans »- not of the slaves of St. Domingue nor of the Haitians ${ }^{49}$.

Also significant in the narrative is the insertion of a news item, Affaire de Bizoton - a local crime in 1863 that took place in the town bearing that name. An entire sub-chapter in the Manuel relates the story in which a little girl who had been missing for days was

46. The relative importance given to the first inhabitants of the island in Haitian pre-history in comparision to the black slaves and their living descendants is especially made clear in Jean Price-Mars statement about the term "Africain" in Haiti : "Quant à celui [terme] 'd'africain', il a toujours été, il est l'apostrophe la plus humiliante qui puisse être addressée à un Haïtien. A la rigueur, l'homme le plus distingué de ce pays aimerait mieux qu'on lui trouve quelque ressemblance avec un Esquimau, un Samoyède, ou un Toungouze plutôt que de lui rappler son ascendance guinéenne ou soudanaise". Ainsi Parla l'Oncle, Montréal, Leméac, 1973, p. 45.

47 . Although Voodoo lacks a formal theology, it has constituted and still constitutes a pillar of Haitian culture today. Sociologist James Leyburn describes it as «...an informal religion of action, not of formal reason. It flourishes because it is malleable, adaptive, suited to the needs of a people living close to nature and without education ». opus cit., p. 135.

${ }^{48}$. Ibid, p. 137.

49. Dorsainvil, p. 66. 
discovered dead- killed as human sacrifice by cult members. Four couples including Jeanne and Congo Pellé were arrested, tried and executed. The crime received much publicity in Haiti and the foreign press made it a subject of lurid and sensationalist news casting Haiti's fragile reputation into an even more negative light. However, Dorsainvils' account of the affair is surprisingly apologetic. Once again the stigma of Africa is present and there is a will to disassociate Haiti from things « imported » from that continent allegedly foreign to Haitians.

«Les romanciers d'aventures exploitèrent l'incident et le dramatisèrent à plaisir. La foule, toujours simpliste et mal informée, conclut que le peuple haïtien, dans l'ensemble, se livrait à d'abominables pratiques importées d'Afrique - Conclusion souverainement injuste, conclusion douloureuse à tout cœur haïtien. Est-il donc besoin de descendre loin dans les Annales des peuples qui marchent au tout premier rang de la civilisation pour retrouver, non pas un fait - mais des séries de faits - plus horribles, plus répugnants que le meurtre reproché à Congo Pellé et à Jeanne Pellé » ${ }^{50}$ !

\section{CONCLUSION}

That the Manuel d'Histoire d'Haiti was written as a political history is significant in two respects. First, on the level of its contents, the emphasis on national unity - while blurring cultural and social divisions and conflicts - aligns the national community behind the ruling class together in one culture and language - French. Indeed, the "identity" or representation of Haiti and that of the Haitian elite often appear superimposed. The fact that the narrative unfolds on the political scene - where French legal and political institutions are appropriated by the Haitian ruling class - contributes strongly to conferring French character to Haitian national identity. The absence of the African roots of Haitian social organization and culture from the pages of the most widely read Haitian history manual goes unnoticed because the Haitian masses themselves have generally been absent from the formal-public sphere - indeed, from Haitian civic life. Secondly, on the epistemological level, the historical study of a nation through classical political history lends well to hidden ideology and

${ }^{50}$. Dorsainvil, pp. $238-239$. 
agendas - which explains why it has been discredited by the social sciences for the past several decades ${ }^{51}$. French historian Pierre Nora states that «the nation » as an object of historical study in the old political history tradition is no longer operative and cogent : C'est au regard de la mémoire seule que la nation dans son acception unitaire garde sa pertinence et sa légitimite ${ }^{52}$. This affirmation is corroborated in the case of the history book examined above. The Manuel d'Histoire d'Haiti itself is an object of mémoire.

51. Gérard Noiriel Population, immigration et identité nationale, Paris, Hachette, 1992, p. 33.

52. Ibid. 


\section{BIBLIOGRAPHY}

Bebel-Gisler Dany et Hurbon Laënnec, Cultures et pouvoir dans la caraïbe, Paris, Éditions L'Harmattan, 1975.

BEBEL-Gisler Dany, La langue créole, force jugulée: Etudes sociolinguistiques des rapports de force entre le créole et le français aux Antilles, Paris, L'Harmattan, 1981.

Bellegarde-Smith Patrick, «Haitian Social Thought in the Nineteeth Century : Class Formation and Westernization », Caribbean Studies, Mar. 1980, Vol. $20 n^{\circ} 1$.

Bellegarde-Smith Patrick, Race, Class and Ideology : Haitian Ideologies for Underdevelopment, New York, AIMS, 1982.

Bellegarde-Smith Patrick, Haiti, the Breached Citadel, Boulder, Westview Press, 1990.

CASimiR-Liautaud Jean, «Haitian Social Structure in the Nineteeth Century » in Working Papers in Haitian Society and Culture, New Haven, ARP-Yale, 1975.

COHEN William B, The French Encounter with Africans 1530-1880: White Response to Blacks, Bloomington, Indiana University Press, 1980.

DORSAINVIL Justin-Chrysostome, Manuel d'histoire d'Haïti, Port-au-Prince, Editions Henri Deschamps, 1925, [1934, 1958].

Dorsainvil Justin-Chrysostome, Histoire d'Haïti, Port-au-Prince, Editions Henri Deschamps, 1942, [1943, 1945].

FAnOn Frantz, Peau noire masque blanc, Paris, Editions de Minuit, 1955.

FERro Marc, Comment on raconte l'histoire aux enfants, Paris, Payot, 1983.

Fleurant Gerdes, «Caste, Class Conflict, and Status Quo in Haiti » in Ethnic Conflicts and Power: A Cross-National Perspective, Donald E. Glefaud eds, 178 193, New York, Wiley, 1973.

Gouriage Ghislain, La Diaspora d'Haïti et l'Afrique, Montréal, Editions Naaman, 1974.

Helen M. Hintjens, Alternatives to Independence: Explorations in PostColonial Relations, Brookfield VT, USA, Dartmouth Publications, 1995.

HoFFMANN Léon-François, «Francophilia and Cultural Nationalism in Haiti » In Haiti - Today and Tomorrow : An interdisciplinary Study, Charles R. Foster and Albert Valdman, eds. pp 57 - 76, Maryland, University Press of America, 1984.

HofFMANN Léon-François, Couleurs, croyances, créole, Montréal, Les éditions du CIDIHCA, 1990. 
Hurbon Laënnec, Dieu dans le vaudou haïtien, Port-au-Prince, Editions Deschamps, 1987.

HuRbon Laënnec, Le barbare imaginaire, Port-au-Prince, Editions Deschamps, 1987.

JAMES C.L.R., Black Jacobins, New York, Random House, 1963. 1941.

LeYburn James G., The Haitian People, New Haven, Yale University Press,

MARCELIN Frédéric, Haïti et l'indemnité française, Paris, Imprimerie Kugelmann, 1897.

MinTZ Sidney W., Caribbean Transformations, New York, Columbia University Press, 1989.

Nicholls David, «A Work of Combat: Mulatto Historians and the Haitian Past, 1847-1867 » in Journal of Interamerican Studies and World Affairs, Feb. 1974, Vol. $16, \mathrm{n}^{\circ} 1$.

Nicholls David, Haiti in the Caribbean Context : Ethnicity, Economy and Revol, London, Macmillan, 1985.

Nicholls David, From Dessalines to Duvalier: Race, Colour and National Independance, London, Cambridge University Press, 1979.

NoIRIEL Gérard, Population, immigration et identité nationale en France XIX ${ }^{e}$ XX $X^{e}$ siècle, Paris, Hachette, 1992.

NoIRIEL Gérard, «La Question nationale comme objet de l'histoire sociale », Genèses, mai, 1991.

Plummer Brenda G., Haiti and the Great Powers, 1902-1915, Baton Rouge, Louisana State University Press, 1987.

Price-MARs Jean, Ainsi parla l'oncle, Montréal, Leméac, 1973, [1st ed. 1928].

SCHNAPPER Dominique, La France de l'intégration, sociologie de la nation en 1990, Paris, Gallimard, 1991.

Trouillot Michel-Rolph, Haiti : State Against Nation, New York, Monthly Review Press, 1990.

VIÉLOT Kléber, «Primary Education in Haiti » in The Haitian Potential, NewYork, Teachers College Press, 1967, 1975. 


\section{Résumé}

$\mathrm{Ce}$ travail examine la formation de l'identité nationale de l'élite haïtienne au cours du dixneuvième siècle. Il porte sur l'appropriation de l'écriture de l'histoire par les classes dominantes et l'usage qu'elles en font pour maintenir le modèle de civilisation et de culture françaises plus d'un siècle après la guerre d'indépendance contre la France. Le manuel histoire d'Haüti de J.C. Dorsainvil (1924) est encore utilisé par les petits Haïtiens entre l'âge de sept à quatorze ans et possède les caractéristiques d'une vraie histoire «nationale»: insistance sur l'unité nationale, batailles de libération en épopée, louange aux pères fondateurs, etc. Ce manuel est analysé comme éléments importants dans la formation et la transmission de l'identité nationale et de mémoire collective de l'élite. La démonstration consiste à révéler les divers moyens à part la langue française - par lesquels la culture française est appropriée et exprimée par l'élite. On a cherché en même temps à déterminer comment les neuf-dixième de la population - consistant en des masses rurales pratiquant le vaudou et parlant seulement le créole - sont intégrés dans cette définition d'Haïtiens de culture française.
Abstract

This study examines the formation of national identity by the Haïtian elite of nineteenth century post-colonial Haïti. It focuses on the appropriation of history writing by the ruling classes and its use in contributing to the maintenance of the French cultural model for over a century and a half after Haïtian independance from France. $J-C$ Dorsainvil's Manuel d'histoire d'Haïti (1924), still read today by all elite children between the ages of seven and fourteen bears the characteristics of a truly "national" history: emphasis on national unity, romantizing of battles of liberation, hailing national heroes, etc.. This history manual is analyzed as a major forger and transmitter of national identity and collective memory. The aim of this article is to demonstrate some of the means - besides the French language - by which French culture is appropriated and expressed by the elite and by which the ninetenths of the population of solely Creole-speaking, voodoo practicing rural masses are integrated into this definition of Haïtian-French national identity.

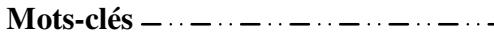

Culture nationale - formation de la nation - histoire $19^{\mathrm{e}}$ et $20^{\mathrm{e}}$ siècles historiographie - identité nationale mémoire - néocolonialisme

Keys-words

Historiography - history $19^{e}$ and $20^{e}$ centuries - memory - national culture national identity - nation-building neocolonialism
} 